\title{
PROTEIN-NUCLEIC ACID INTERACTION
}




\section{TOPICS IN MOLECULAR AND STRUCTURAL BIOLOGY}

Series Editors

Stephen Neidle

Institute of Cancer Research

Sutton, Surrey, UK

Watson Fuller

Department of Physics

University of Keele, $U K$

Volume 1 Topics in Nucleic Acid Structure, Part 1

Edited by Stephen Neidle (1981)

Volume 2 Topics in Nucleic Acid Structure, Part 2 Edited by Stephen Neidle (1982)

Volume 3 Molecular Aspects of Anti-Cancer Drug Action Edited by Stephen Neidle and Michael Waring (1983)

Volume 4 Biomembrane Structure and Function Edited by Dennis Chapman (1984)

Volume 5 Connective Tissue Matrix Edited by David Hukins (1984)

Volume 6 Metalloproteins, Part 1: Metal Proteins with Redox Roles Edited by Pauline Harrison (1985)

Volume 7 Metalloproteins, Part 2: Metal Proteins with Non-Redox Roles Edited by Pauline Harrison (1985)

Volume 8 Polysaccharides

Edited by E.D.T. Atkins (1985)

Volume 9 Topics in Nucleic Acid Structure, Part 3

Edited by Stephen Neidle (1987)

Volume 10 Protein-Nucleic Acid Interaction

Edited by Wolfram Saenger and Udo Heinemann (1989) 


\title{
PROTEIN-NUCLEIC ACID INTERACTION
}

\author{
Edited by
}

\section{WOLFRAM SAENGER and UDO HEINEMANN}

\section{Institut für Kristallographie}

Freie Universität Berlin,

West Germany

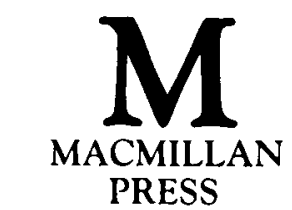

Scientific \& Medical 
(C) The Contributors 1989

Softcover reprint of the hardcover 1st edition 1989 978-0-333-45321-6

All rights reserved. No reproduction, copy or transmission of this publication may be made without written permission.

No paragraph of this publication may be reproduced, copied or transmitted save with written permission or in accordance with the provisions of the Copyright Act 1956 (as amended), or under the terms of any licence permitting limited copying issued by the Copyright Licensing Agency, 33-4 Alfred Place, London WC1E 7DP.

Any person who does any unauthorised act in relation to this publication may be liable to criminal prosecution and civil claims for damages.

First published 1989

Published by

THE MACMILLAN PRESS LTD

Houndmills, Basingstoke, Hampshire RG21 2XS

and London

Companies and representatives

throughout the world

Typeset by Wearside Tradespools Ltd

Fulwell, Sunderland

British Library Cataloguing in Publication Data

Protein-nucleic acid interaction

1. Organisms. Nucleic acids. Interactions

with proteins. 2 . Organisms. Proteins.

Interactions with nucleic acids

I. Saenger, Wolfram II. Heinemann, Udo

III. Series

$574.87^{\prime} 328$

ISSN 0265-4377

ISBN 978-1-349-09873-6

ISBN 978-1-349-09871-2 (eBook)

DOI 10.1007/978-1-349-09871-2 


\section{Contents}

The contributors $\quad$ ix

Preface $\quad x i$

1 DNA-Protein Interactions in the Regulation of Gene

Expression Peter H. von Hippel and Otto G. Berg 1

Introduction 1

Single Protein Binding to a Regulatory DNA Site 2

Levels of Specificity 3

Conclusions, Applications, Further Developments and More
Complicated Problems

2 Structures of Protein-Nucleic Acid Complexes in Solution by Electro-optical Analysis Dietmar Porschke and Jan

Antosiewicz

Introduction 19

Electro-optical Experiments $\quad 19$

Short Description of Hydrodynamic Model Calculations 21

Repressor Proteins with Large Permanent Dipole Moments of about 1000 Debye Units

DNA Double Helices Modelled by Beads 25

Tet Repressor-Operator Complex 26

Complexes Formed by cAMP Receptor with Promotor DNA

$\begin{array}{ll}\text { Conclusions } & 32\end{array}$ 
3 NMR Studies of Protein-DNA Recognition. The Interaction of LAC Repressor Headpiece with Operator DNA Robert

Kaptein, Rolf Boelens and Rolf M. J. N. Lamerichs

Introduction

Biomolecular Structures from NMR

Structure of Lac Repressor Headpiece

Lac Operator Fragments

Lac Headpiece-Operator Complexes

Conclusions

4 The Single-Stranded DNA Binding Protein of Escherichia coli:

Physicochemical Properties and Biological Functions Joachim

Greipel, Claus Urbanke and Günter Maass

Introduction

Physical Properties and Structure of EcoSSB

Purification of EcoSSB

Concentration Determination of EcoSSB

Structural Features of EcoSSB-DNA Complexes

Interactions of $E$. coli Single-stranded DNA Binding Protein with Other Proteins

Interactions of EcoSSB with Nucleic Acids

Kinetics of the Binding of EcoSSB to Single-stranded DNAs

Concluding Remarks

5 Protein-Nucleic Acid Interactions in Tobacco Mosaic

Virus Gerald Stubbs

Introduction

Nucleotide Sequence

Specific Affinities Between TMV Coat Protein and RNA

Three-dimensional Structure of TMV RNA

Viral Assembly and Disassembly

6 Structural and Functional Studies of Ribonuclease T1 Udo

Heinemann and Ulrich Hahn

Introduction

Crystallographic Studies of Ribonuclease T1

Other Biophysical Studies of Ribonuclease T1

Ribonuclease T1 Folding

Site-directed Mutagenesis of Ribonuclease T1

Related Fungal and Bacterial Ribonucleases

Conclusions 
7 Tet Repressor-Tet Operator Interaction Wolfgang Hillen and Andreas Wissmann

Tetracycline Resistance Determinants in Gram-negative Bacteria

Preparation of Tet Repressor Proteins and tet Operator Containing DNA Fragments

Tet Repressor-tet Operator Binding

Thermodynamics and Kinetics of tet Operator-Tet Repressor Interactions

DNA Binding Motif of Tet Repressor

Contact Sites of the tet Operator DNA with Tet Repressor

Contacts of Tet Repressor to tet Operator

Spatial Structures of Tet Repressor and the Tet Repressor-tet

Operator Complex

8 Structure and Condensation of Chromatin $M$. H.J. Koch

Introduction

The Chromatin Structure

The Structure of Chromatin in Solution $\quad 164$

Uncondensed Chromatin 168

Condensed Chromatin $\quad 173$

Chromatin in Gels and Nuclei 177

Orientation of the Nucleosomes and of the Linker DNA 177

Location of $\mathrm{H} 1$

Kinetics of Condensation $\quad 184$

Solubility Properties 184

Intrinsic Solubility Properties of Chromatin 185

Effect of Cations on Condensation and Solubility $\quad 187$

A Gallery of Models $\quad 195$

Conclusion $\quad 200$

$\begin{array}{ll}\text { Index } & 205\end{array}$ 


\section{The Contributors}

Jan Antosiewicz

Max-Planck-Institut für

biophysikalische Chemie

3400 Göttingen

West Germany

\section{Otto G. Berg}

Department of Molecular Biology

Uppsala University Biomedical Centre

Box 590

75124 Uppsala

Sweden

\section{Rolf Boelens}

Department of Chemistry

University of Utrecht

Padualaan 8

3584 CH Utrecht

The Netherlands

\section{Joachim Greipel}

Medizinische Hochschule Hannover

Zentrum Biochemie

Abt. Biophysikalische Chemie

3000 Hannover

West Germany

\section{Ulrich Hahn}

Institut für Kristallographie

Freie Universität Berlin

Takustr. 6

1000 Berlin 33

West Germany
Udo Heinemann

Institut für Kristallographie

Freie Universität Berlin

Takustr. 6

1000 Berlin 33

West Germany

\section{Wolfgang Hillen}

Lehrstuhl für Mikrobiologie

Institut für Mikrobiologie und

Biochemie

Staudtstr. 5

8520 Erlangen

West Germany

Peter H. von Hippel

Institute of Molecular Biology

University of Oregon

Eugene

OR 97403

USA

Robert Kaptein

Department of Chemistry

University of Utrecht

Padualaan 8

3584 CH Utrecht

The Netherlands

\section{H. J. Koch}

European Molecular Biology

Laboratory

clo DESY

Notkestr. 85

2000 Hamburg 52

West Germany 
Rolf M. J. N. Lamerichs

Department of Chemistry

University of Utrecht

Padualaan 8

3584 CH Utrecht

The Netherlands

Günter Maass

Medizinische Hochschule Hannover

Zentrum Biochemie

Abt. Biophysikalische Chemie

3000 Hannover

West Germany

Dietmar Porschke

Max-Planck-Institut für

biophysikalische Chemie

3400 Göttingen

West Germany

\section{Gerald Stubbs}

Department of Molecular Biology

Box 1820, Station B

Vanderbilt University

Nashville

TN 37235

USA

Claus Urbanke

Medizinische Hochschule Hannover

Zentrum Biochemie

Abt. Biophysikalische Chemie

3000 Hannover

West Germany

\section{Andreas Wissmann}

Lehrstuhl für Mikrobiologie

Institut für Mikrobiologie und

Biochemie

Staudtstr. 5

8520 Erlangen

West Germany 


\section{Preface}

Protein-nucleic acid interactions have been a focal point of scientific interest over the past three decades. The number of exciting papers that appear annually on this topic is breathtaking. Therefore, it could not be our intention to provide with this volume a comprehensive overview of the field. Instead, we have chosen to bring together contributions describing a wide range of problems in the field of protein-nucleic acid interactions investigated by a variety of techniques.

This volume begins with a chapter on DNA-protein interactions in the regulation of gene expression, which may serve as a convenient entry point into the book. The remaining chapters may be read in any order, since each is devoted to a selected model system. These cover several orders of magnitude in size, going from small proteins like Lac repressor headpiece and RNase $\mathrm{T} 1$ and their cognate nucleic acid fragments to chromatin, thus reflecting the amazing diversity of problems even in a fairly well-defined scientific field such as the present. Our main emphasis in putting together this volume has been to include all important techniques currently used in studying protein-nucleic acid interactions. We believe that this aim has been reached within the limits imposed by the size of the book. It goes without saying, and becomes perfectly clear when reading this volume, that only the interplay of the various techniques may be expected to bring about new developments in this field.

Without the very careful work of the contributors, this volume would not have been possible. We would like to thank all authors for their diligence, Stephen Neidle and Watson Fuller, the series editors, for the impetus to assemble this book and Harry Holt and David Grist of The Macmillan Press for their patience and good co-operation. 